\title{
THE HISTORY OF DIPLOMATIC RELATIONS BETWEEN ROMANIA AND 1 NORWAY DURING THE INTERWAR PERIOD
}

\author{
Ana-Maria Despa \\ Valahia University of Târgovişte, E-mail address: anna3twin@yahoo.com
}

\section{Acknowledgments}

This paper has been presented at the Second International Conference on Nordic and Baltic Studies in Romania: Black Sea and Baltic Sea Regions: Confluences, influences and crosscurrents in the modern and contemporary ages hosted by the Romanian Association for Baltic and Nordic Studies, Târgoviste, May 20-22, 2011 and was funded from the European Union Structural Funds project "The Predex Programme for Excellence in Doctoral Training for the Society of Knowledge" of Valahia University (Contract Code: POSDRU/CPP107/DMI1.5/S/77497)

\begin{abstract}
:
This article aims at reconstructing on the basis of diplomatic archives records the history of diplomatic and consular relations between the two countries during the interwar period. The diplomatic bonds between the two countries date back already before Norway had obtained its sovereignty by dissolving the United Kingdom of Sweden and Norway in 1905. Eventually, Romania recognized the Norwegian independence and conducted diplomatic relations with Norway through its legation in Berlin. The first official legation in Norway was established in 1917 by Grigore Bilciurescu's appointment as chargé d'affaires in Christiania (Oslo). On the other hand, the first Norwegian diplomat who resided in Bucharest was Terje Knudtzon in 1935. During most of the interwar period the diplomatic relations between the two countries were conducted through envoys residing in other European capitals. The article fits into the category of historical evidence works and since it has adopted a chronological approach, it does not raise, more than is necessary, the prospect of a theoretical interpretation of these relations.
\end{abstract}

\section{Rezumat:}

Acest articol îşi propune, pe baza arhivelor diplomatice, să reconstituie istoria relațiilor diplomatice si consulare dintre cele două țări în perioada interbelică. Contactele diplomatice dintre acestea datează $\hat{\imath} n c \breve{a}$ din perioada anterioară obținerii suveranității Norvegiei prin dizolvarea Regatului Unit al Suediei şi Norvegiei în 1905. România a recunoscut independența Norvegiei şi a desfăşurat relații diplomatice $\mathrm{cu}$ aceasta prin intermediul legației sale la Berlin. Prima legație în Norvegia a fost înființată în 1917 prin numirea lui Grigore Bilciurescu ca insărcinat cu afaceri $\hat{\imath}$ Christiania (Oslo). Pe de altă parte, primul diplomat norvegian care a locuit în Bucureşti, a fost Terje Knudtzon $\hat{\imath}$ 1935. In perioada 
The history of diplomatic relations between Romania and Norway during the interwar period

interbelică relațiile diplomatice dintre cele două țări s-au derulat prin intermediul legațiilor deschise în alte capitale europene. Acest articol se încadrează în categoria lucrărilor de evidență istorică şi întrucât a ales o abordare cronologică, el nu are în vedere, mai mult decât este necesar, perspectiva unei interpretări teoretice a acestor relatii.

Keywords: Romania; Norway; bilateral relations; interwar period

\section{Context}

For a long time, Romanians regarded Northern Europe as a remote geographical area and hence they did little to enhance their knowledge of it. According to the opinion of some experts in the field ${ }^{1}$, the cause of this fact is due, in the first phase, to geographic distance and then to the cultural, social and economic differences between the two areas ${ }^{2}$. These differences have partly inhibited the motivation for initiating and maintaining relationships of any kind, including those of diplomatic, economical or cultural character. The progress in technology and logistics occurring in the 19th and beginning of 20th centuries and the widening of the network of diplomatic bonds among European countries that followed the First World War led to a "shrink" of geographical distances and had a positive effect on Romania's relations with the Nordic nations. Even so, the contacts between Romania and the Nordic countries in the interwar period did not acknowledge a sudden upswing and their evolution was not always a linear one.

The relations between Romania and Norway do not deviate from the general trend described above as I will prove in this article. In this article I will approach, as a general objective, the chronological reconstruction of the history of diplomatic relations between Romania and Norway in the interwar period. The analysis will have as a starting point the setting up of the first Romanian diplomatic office in the capital of Norway in 1917 and will cover all stages of evolution of the diplomatic relations between the two countries to the closing up of the Romanian Legation in Oslo following the occupation of Norway by German troops in the spring of 1940. The article fits into the category of "historical evidence" works $^{3}$, and as such, it does not raise, more than is necessary, the prospect of a theoretical interpretation of these relations, a subject that is intended to be the core of a separate study. The article is based on the systematic

\footnotetext{
1 See for example Silviu Miloiu, Oana Laculiceanu-Popescu and Elena Dragomir, O conceptie romaneasca a Nordului, sec. XIX-XX, (Targoviste: Editura Cetatea de Scaun, 2009).

2 Miloiu, Laculiceanu and Dragomir, 9.

3 Ibid., 117.
} 
research of archival documents. However, writing the history of the diplomatic relations between the two states, even from an inventory point of view, cannot be achieved outside the international context.

The intention to investigate the subject is motivated by the fact that the issue is highly neglected in the historiography of the field. If the history of diplomatic relations between Romania and the Western European countries has enjoyed substantial attention from researchers, the study of Romania's relations with the countries placed at Europe's periphery is part of a new current in Romanian historiography. Part and parcel of this new current in historiography, the research of relationship with Northern European countries of Finland, Denmark and Sweden has attracted some measure of interest and was the subject of recent works in the field, while the relations with Norway have been less discussed in the historical literature. An exception to this pattern makes the volume of documents entitled Romanian-Norwegian Relations. Diplomatic Documents 1905-1947 published under the Romanian Cultural Institute aegis in 2007 and a chapter of Vasilica Sarbu's PhD thesis entitled The Nobel Peace Prize in the interwar period (1918-1939)4. The documents edited by a bundle of Romanian and Norwegian historians (Jardar Seim, Stelian Obiziuc and collaborators) start from 1905, the year of Norway's independence, and end in 1947, the year of resumption of diplomatic relations between the two countries following the World War II. Due to the intensity of diplomatic exchanges, the editors consider this period as representative for the history of diplomatic relations between Romania and Norway. Although an important contribution to the knowledge of Romanian-Norwegian relations, the work is limited to the publication of official documents that provide the main lines of the diplomatic relations between the two countries without revealing the complexity of these bonds through the publication of related documents. Vasilica Sîrbu's chapter undertakes, in the context of Romanian nominations for the Nobel Prize in the interwar period, a brief review of diplomatic relations between Romania and Norway. The author uses as the main bibliographic source the aforementioned collection of documents ${ }^{5}$ and consequently the account of events and of the dynamic of diplomatic relations between the two states do not deviate from the direction laid down by the documents published in this reference work. The topic covered by this article is sporadically treated

\footnotetext{
4 Vasilica Sarbu, Premiile Nobel pentru Pace in perioada interbelica (1918-1939) (Iasi: Ph. D thesis, Al. I. Cuza University, 2010).

${ }^{5}$ Jardar Seim, Stelian Obiziuc et. al. ed., Romanian-Norwegian Relations, Diplomatic Documents, 1905-1947 (Bucuresti : Institutul Cultural Român, 2007).
} 
in other works of general knowledge regarding the diplomatic relations between Romania and the Nordic states ${ }^{6}$.

Such as Sîrbu's chapter, the basis of documentation for the first part of this study is formed by documents already published by Seim and Obiziuc. Instead, in the second part of the study other archive documents from the Romanian Ministry of Foreign Affairs are used: reports of plenipotentiary ministers accredited to these countries, diplomatic dispatches, telegrams exchanged between the Royal Houses of the two constitutional monarchies, notes from the specified period.

\section{Beginnings}

Given the fact that the establishment of bilateral relations between states require them to be independent and sovereign, we cannot discuss about diplomatic relations with Norway until this country's independence was not gained by the peaceful separation from the union with Sweden on October 31, 1905. Both Sweden and Norway informed the Romanian state on the new international status of the latter country7. In a letter dispatched by the Norwegian Foreign Minister to its Romanian counterpart, it was expressed Norway's intention of setting up official relations between the two countries and creating a consular mission in Romania ${ }^{8}$. The Romanian Ministry of Foreign Affairs confirmed the receipt of the notification of the proclamation of independence by Norway and expressed the desire to establish formal relations with the Scandinavian state. The two countries agreed to entrust their legations in Berlin with the mission of watching over their interests in Oslo and Bucharest respectively ${ }^{9}$. The opening of diplomatic ties process proved to be characterized from the beginning by the desire and effort of the two countries to expand their relations.

Eventually, the intensification of contacts between Romania and Norway and the closing down of the Romanian legation in Berlin that had previously mediated Romania's diplomatic relations with the Scandinavian countries required the establishment of permanent diplomatic missions in

\footnotetext{
${ }^{6}$ See, for exemple, Nicolae Iorga, Țări scandinave: Suedia şi Norvegia. Note de drum şi conferințe, ed. Silviu Miloiu (Târgovişte: Valahia University Press, 2008); Miloiu, Laculiceanu and Dragomir; Silviu Miloiu, „Fețele schimbătoare ale stângii norvegiene de la jumătatea anilor 1930: percepții şi reacții româneşti," in Politică, diplomație şi război. Profesorul Gheorghe Buzatu la 70 de ani, coord. Sorin Liviu Damean, Marusia Cârstea (Craiova: Ed. Universitaria, 2009), 396-404.

7 Seim and Obiziuc, 29- 30.

8 Ibid., 31.

${ }^{9}$ Ibid., 34-35.
} 
The history of diplomatic relations between Romania and Norway during the interwar period

the capitals of two states ${ }^{10}$. Grigore Bilciurescu11 was appointed in the capacity of Envoy Extraordinary and Minister Plenipotentiary at Christiania ${ }^{12}$ and presented his credentials on June 8 / 21, 1917. The establishment of the first Romanian Legation in Norway's capital occurred in the context of World War I conflict. At the beginning of the war, like other Scandinavian states, Norway adopted a position of neutrality. The country experienced an important economic growth as a result of its capacity of maintaining commercial ties with both warring camps. Norway, a country with wide open port whose economy was based on trade and shipping, wanted broadening markets for local products, especially cereals. As for Romania, maintaining good relations with a neutral state, such as Norway, could bring about significant economic benefits. The affirmation of Romania's envoy to Oslo Dimitrie Jurascu who two decades later in his report dated January 4, 1939 drew the attention of Romanian Minister of Foreign Affairs Grigore Gafencu that:

"The Northern European countries are playing an important role in the international exchange of goods. Their trade with foreign countries reaches figures that evoke a particular interest in comparison to other countries. (...) Customarily, the existence of these countries largely depends on their external trade"13

was no less appropriate to describe the situation of these countries during WWI than during the interwar period or the beginning of WW II. Therefore, we can conclude that the first impulse for developing the relations between the two countries was economic.

As such, one of the first achievements of the relations between the two states was the signing of a Maritime and Commercial Convention in

\footnotetext{
10 The closing down of the Romanian diplomatic office in Germany's capital was caused by Romania's decision to enter the war on Entente's side.

11 Grigore Bilciurescu (1874-1939). Graduated in 1895 of the Faculty of Law of University of Bucharest with the BA thesis entitled Conditiunea juridica a strainilor in Romania [The juridical status of foreigners in Romania], he eventually joined the Foreign Ministry. He was appointed Charge d'Affaires in Stockholm (13/16 November 1916). By Royal Decree no. 408 dated May 3/16, 1917 issued in Iasi, Grigore Bilciurescu was posted from May 1, 1917 as envoy to the Norwegian capital.

12 Christiania or Kristiania - the name of Norwegian capital from 1624 until 1924 when it was changed in Oslo as a result of the spelling reforms aimed at eliminating the Danish influences in Norwegian language.

13 Arhivele Diplomatice ale Ministerului Afacerilor Externe al României (The Diplomatic Archives of the Romanian Foreign Ministry, hereafter AMAE), Folder 71/1939-1940, Norvegia, vol 11, Dispatch no. 18 of 04.01.1939 to Foreing Affaires Minister, Grigore Gafencu, 11-15.
} 
Berlin on March 18/31 191014, denounced by the Romanian party in April $1921^{15}$.

Romania's interests in Norway were also political. Already before declaring its neutrality, Romania was striving for signing secret agreements with the Entente powers in order to enlist support in its bid to achieve the unification with Transylvania ${ }^{16}$. The purpose of Romania's participation in the WW I was the recovering of the Austria-Hungary's provinces inhibited by Romanian majorities. In this respect, the Romanian foreign policy was to attract the support of as many European countries as possible, which also explains the purpose and interest regarding Norway's position.

An interesting episode in the history of diplomatic relations between Romania and Norway, which also highlights the good cooperation between them, occurred in early 1918 when Norway was required to represent Romania's interests in the Russian capital, Petrograd. Having as a background the Russian Revolution and the conflict regarding the entering of Romanian army in Bessarabia ${ }^{17}$, the Romanian-Russian diplomatic ties were broken on January 13/28, 1918 at the initiative of the Russian party ${ }^{18}$. The Romanian Legation and all the representatives of the Romanian authorities in Russia were first arrested and eventually expelled in great haste. At the request of his Romanian counterpart, Nikolai Prebensen, the Norwegian envoy at Petrograd, requested the approval of the Foreign Ministry in Oslo to take over and represent the interests of Romania in Petrograd ${ }^{19}$. Before receiving confirmation from Norway, Romania's interests were represented by the French Legation. Soon, the French

\footnotetext{
14 Seim and Obiziuc, 36-37.

15 Ibid., 49.

16 Gheorghe Platon et al., ed., Istoria Romanilor, Vol. VII, Tom. II, De la indepenendenta la Marea Unire (1878 - 1918) (Bucuresti: Editura Enciclopedica, 2003), 398.

17 The fall of the Tsarist regime contributed to social unrest and instability in Bessarabia. When the Bolshevik forces intervened to restore order, the Country Council asked for help of the Romanian government. Thus, in January 1918 the Romanian army crossed the Prut River with the aim of maintaining order and liberating Bessarabia. The immediate consequence of these events was the confiscation of the Romanian Treasure by the Russian Government. The Romanian Treasure contained the National Bank of Romania's private collections, documents and heritage goods, art objects and jewelry, etc. The Treasure was sent to Russia during the First World War in order to be protected from the threat of falling into the Central Powers' hands. Another consequence was the arrest and internment in the Petropavlovsk of Romanian diplomatic corps in the Russian capital led by envoy Constantin Diamandy. They were released several days later following the intervention of the Entente's diplomatic corps.

18 Ion Ciuperca, Romania in fata recunoasterii unitatii nationale. Repere (Iasi: Editura Universitatii „Al. I. Cuza”, 1996), 35.

19 Seim and Obiziuc, 43.
} 
The history of diplomatic relations between Romania and Norway during the interwar period

diplomats indicated their intention to leave the Russian capital, so the defense of Romanian interests was transferred to Norwegian representatives. In February 1918, N. Prebensen received the consent to handle Romanian interests in the Russian capital ${ }^{20}$. In these circumstances, Bilciurescu received from the Norwegian Minister of Foreign Affairs and forwarded to the government in Bucharest the list of expenses made by the Norwegian part with regard to the defence of Romanian interests in Petrograd. During the same year the remaining part of the Romanian representatives in Russia sought the help of the Romanian Government through Chargé d'affaires in Stockholm, Michael A. Arion ${ }^{21}$. They were unable to leave Russia or recover the archives of the former Romanian Legation in Russian capital. The Romanian envoy in Stockholm intervened at the Romanian Legation in Christiania, which was able to enlist the backing of the Norwegian government in order to solve which issue. Arion's request was that the Legation from Christiania should obtain from the Norwegian part for the Romanian officials who were already in a critical situation the right to be treated as Norwegian citizens in Russia. The Norwegian legation in Petrograd was also requested to provide with the Norwegian passport those Romanians who wanted to take refuge in the Scandinavian countries. In a telegram dispatched to Ion I.C. Bratianu, Bilciurescu informed that as a result of the steps taken by the Norwegian part, the Central Committee of the Russian People Commissariat had informed the Norwegian Consulate in Moscow that the Romanian citizens were allowed to return to Romania22. The diplomatic support given, whenever possible, by Norway to Romania in this dramatic episode of Romania's strained relations with Russia was a herald of good diplomatic relations to be developed between the two countries.

The Romanian Legation in Norway's capital will function from 1917 until 1922 when it will be closed for financial reasons ${ }^{23}$. The diplomatic activity of Bilciurescu in the capital of Norway was prolific and advanced

\footnotetext{
20 Ibid., 45. Ciphered telegram dated February 25, 1918.

${ }^{21}$ Dumitru Preda et. al., ed., Romania la Conferinta de Pace de la Paris (1919-1920) (Bucuresti: Editura Semne, 2010), 40. Radiograms from Mihail A. Arion, Charge d'Affaires in Stockholm to Ion I.C. Bratianu, President of the Council of Ministers and Minister of Foreign Affairs of Romania, regarding the situation of the Romanian officials in Russia and the recovery of the archives of the former Romanian Legation in Petrograd. Telegram no. 666 sent on December 10 and received on December 22, 1918 according to Telegram no. 690 dated January 3, 1919. See page no. 68 , doc. no. 82.

22 Ibid., 40. Telegram no. 825 of December 24 / January 6, 1919 from Grigore Biclciurescu to the President of the Council of Ministers and Minister of Foreign Affairs of Romania.

23 Seim and Obiziuc, 50. Royal Decree no 1178 of 09.03.1922 regarding the suppression of Romanian diplomatic offices abroad, including those in Norway and Finland.
} 
the Romanian interests. For instance, the request of Hungary's protestant churches addressed to the Nordic kings for protection "against the threatening destruction of Hungary which was the most advance dam of Protestantism in Eastern Europe" was an attempt of contesting the new borders established after World War I.24 In order to clarify the situation, the Romanian diplomat asked for an audience to King Haakon VII to whom he presented the religious and nationalities situation in Transylvania. The Romanian diplomat also highlighted the great tolerance of the Romanian government and nation as regards the religion, nationality, culture and customs of minorities living within Romania's new borders. Bilciurescu's views were shared by King Haakon VII who adopted a favourable position concerning the Romanian cause. With the downfall of the large multinational empires following the World War I, such challenges to the new Romanian borders by Budapest were frequent. The rumours spread by Hungarian representatives in the Norwegian and German press regarding the troubled situation in Transylvania and an alleged uprising in Cluj on November 30, 1919, which the government in Bucharest had violently and bloodily suppressed, fall into the same category. ${ }^{25}$ In his response, Bilciurescu emphasized in a letter published in Tidens Tegn "the absurdity of the news from the telegram, their origins and trends" 26 . The Romanian diplomat also requested from the Romanian Legation in France for concrete information from inside the country in order to give an official disclaimer. Victor Antonescu, the Romanian envoy in Paris, assured his colleague in the capital of Norway that: «Nouvelles annonçant révolution socialiste ou paysanne en Roumanie sont complètement fausses. Vous pouvez les démentir. Situation pays calme. Ordre règne partout ${ }^{27}$. Based on this document, Bilciurescu formulated a refutation of such defamatory news against Romania and asked it to be published in the same Norwegian newspaper, Tidens Tegn, informing of this Ion I.C. Bratianu, the President of the Council of Ministers and Minister of Foreign Affairs of Romania who

\footnotetext{
24 Ibid., 45. Confidential Report no. 820 of 12/25.12.1918 of the Romanian envoy in Christiania, Grigore Bilciurescu to Prime Minister Ion I.C. Bratianu.

25 Preda 2010, 20. Document no. 20 - Telegram no. 573 of 19.12 .1919 of Grigore Bilciurescu to the Romanian Ministry for Foreign Affairs.

26 Ibid.

27 "The announcement of a new peasant or socialist revolution in Romania is completely false. You can deny. The situation in the country is calm. Order reigns everywhere", Ibid., 191-192. Telegram from Grigore Bilciurescu to Mihail I. Pherekyde, The interim President Council of Ministers and Minister of Romanian Foreign Affairs regarding the retraction of the Norwegian press rumors of an alledged troubled situation in Transylvania.
} 
was also the head of the Romanian delegation during the Paris Peace Conference $^{28}$.

Taking into consideration the status of both Romania and Norway in the context of the new international realities in the aftermath of World War I, we can say that both countries were now in a similar position of "minor powers" suffering various perceived or real pressures and threats coming from the great powers ${ }^{29}$. Although during the World War I Norway had maintained neutrality, when the conflagration ended, in the context of new international realities, it abandoned its policy of isolation and joined the League of Nations on March 4, 192030. The reasons why Norway decided to join this international body were based upon the Norwegian state's intention to promote the principles of security and peaceful resolution of conflicts but also upon its desire to avoid international isolation. Moreover, given the fact that Norway belonged to the small countries' category and its influence in international decision-making was directly proportional to its size and number of inhabitants, being active in the international system allowed her to promote its peaceful foreign policy and its interests to another level.

On the other hand, by signing the Paris peace treaties, Romania became a founding member of the League of Nations. Its foreign policy aimed at organizing a security system by entering into alliances with former belligerent and non-belligerent states in order to assure the confirmation of its new boundaries. One of political figures who campaigned for this goal during the Paris Peace Conferences was Nicolae Titulescu, a representative figure of the Romanian diplomacy in the interwar period. With respect to the personality of the Romanian diplomat and the role he played at the League of Nations, the Norwegian Foreign Minister J.L. Mowinckel ${ }^{31}$ appreciated in a discussion with the Romanian envoy Barbu Constantinescu ${ }^{32}$ that:

«Monsieur Titulesco a été surement le meilleur Président de la Ligue, et le plus habile aussi. C'est un grand bonheur pour votre pais d'avoir un Ministre des Affaires Étrangers de son envergure. Vis-à-vis de l'étranger

\footnotetext{
28 Ibid., $172-173$.

${ }^{29}$ Miloiu, Laculiceanu and Dragomir, 9.

30 Silviu Miloiu, O istorie a Europei Nordice si Baltice. Vol. I - De la epoca nationalismului la Razboiul Rece (Targoviste: Editura Cetatea de Scaun, 2003), 109.

31 Johan Ludwig Mowinckel (1870 - 1973) - Norwegian politician original from Bergen, distinguished himself in both external and internal politics leading three governments in the interwar period.

32 Barbu Constantinescu (1886 - 1948) - Romanian jurist and diplomat, accredited to Romanian diplomatic missions in Stockholm and Scandinavia since 28.06.1923.
} 
The history of diplomatic relations between Romania and Norway during the interwar period et de son monde, que lui connait a la perfection, c'est d'un immense intérêt pour n'importe quel pays. »33

That fact that Titulescu was so highly appreciated in the society of diplomats in Geneva had a positive impact on the influence of Romania on the international arena and on the development of Romania's relations with other countries.

By and large, one can observe a synchronization of the foreign policy objectives of the two countries at the League of Nations at least in the first stage of its existence. By their activity in support of this organism, Romania and Norway sought to preserve their integrity and sovereignty by maintaining peace in Europe and counterbalancing the emerging Great Powers. According to article 10 of the Pact of the League of Nations, the signatories were committed to respect and maintain the territorial integrity and political independence of all members ${ }^{34}$.

Yet, differences in the vision of the two states regarding the League of Nations can be noticed and the worsening of the international climate threatening with the outbreak of a new world war served to deepen them. This became obvious in spring of 1936 during a meeting between Gheorghe Tatarescu, the Romanian Prime Minister, and Havdan Koht ${ }^{35}$, the Norwegian Foreign Minister. During a trip occasioned by his participation in the National History Conference organized in Bucharest, Koht expressed his country's position on the new European developments. On his way to Romania, Koht had visited several European capitals with the stated purpose of making an "exchange of ideas on the international situation created by German policy" according to envoy Dimitrie Jurascu ${ }^{36}$. In his discussion with Prime Minister Tatarescu, whom he met in the absence of Foreign Minister Titulescu, Koht explained the basic conceptions behind the Norwegian foreign policy and the scope of his visit to European capitals. In accordance with the peaceful principles promoted by his country at the League, he argued that small and medium sized countries

\footnotetext{
33 Seim and Obiziuc, 92-93, Dispatch no. 1702 of 26.10.1933, Oslo.

34 Ioan Scurtu, Istoria romanilor intre anii 1918-1940, Pactul Societatii Natiunilor. http://ebooks.unibuc.ro/istorie, accessed at 20.04.2011.

35 Halvdan Koht (1873 - 1965) - Professor of history and Norwegian diplomat, in 1936 as a Foreign Minister was the one who supported a shift in Norway's foreign policy under the impact of the failure of League of Nations. Norway will no longer back any League of Nations' decisions that were not based on the principles of equality and universality and will move towards a system of alliances with northern states, Silviu Miloiu, $O$ istorie a Europei Nordice si Baltice. De la epoca nationalismului la Razboiul Rece, Vol. I (Targoviste: Editura Cetatea de Scaun, 2003), 162.
}

36 AMAE, Folder 71/1920-1944, Norvegia, vol. 13, 128. 
should obtain at least a moral influence on the decisions of major powers in order to prevent conflicts. Discussions were held on the latest decisions taken at the League of Nations ${ }^{37}$ and reached a deadlock when the Romanian representative expressed his support for the rearming of states and of the League of Nations. The views of the Romanian chief of diplomacy ran contrary to the non-aggression policy and dispute resolution by arbitration as expressed by Norway at the League of Nations and Koth regarded with scepticism Tatarescu's opinions. This disagreement is relevant with regard to the differences manifesting in the foreign policy conduct of the two countries, which were based on the interpretation of their national interests in the context of the new international realities. If Norway's foreign policy was driven by the idea of conservation and the desire to keep at bay from a possible conflict, the Romanian policy was based on the defence of the territorial integrity by any means, be they diplomatic or military. Norway "considered itself to be a security supplier and not a consumer" 38 , especially because it "feels safe" having no major conflicts with its neighbors. Instead, Romania, besides maintaining national unity, aimed at economical and administrative uniformisation, which could only be achieved during peacetime. However, a common point existed in the foreign policy goals of the two countries, namely the desire to preserve peace on the continent and the efforts that should be made in order to prevent the outbreak of a new war. ${ }^{39}$ The diplomatic ties between Romania and Norway and their bonds within the League of Nations during this period were overshadowed by their relations with Europe's great powers and with their neighbouring states.

The Romanian Legation in the Norwegian capital operated until April 1, 1922 when King Ferdinand I decided the closing down of several diplomatic missions in Europe ${ }^{40}$. This decision was taken during a period of financial stress that Romania was crossing and was motivated by budgetary constraints. A new Romanian legation in Norway's capital was

\footnotetext{
37 In 1933 Germany left the League of Nations and in March 1936 began the remilitarization of Rhenania. The League of Nations decides not to intervene. The Pro-German attitude of Norway was motivated by Norway's acknowledgement of the common roots of the two states, but foremost by the Scandinavian economic interests.

38 Miloiu 2003, 165.

39 Seim and Obiziuc, 128-129. Dimitrie Jurascu, the Plenipotentiary Minister in Oslo, to the Romanian Minister of Foreign Affairs regarding the discussion with the French envoy in Norway's capital about the critical international situation and the prestige of the League of Nations.

40 Ibid., 50. Royal Decree no. 1178 of 9.03 .1922 regarding the closing down of the Romanian legations in Portugal, Netherlands, Spain, Norway, Finland, Tokyo and of the diplomatic agency in Egypt.
} 
not open until 1934. However, in order to continue the diplomatic relations between Romania and Norway, another royal decree was issued by which Mihail M. Paclianu ${ }^{41}$ was appointed envoy in Stockholm, Copenhagen, Christiania and Helsinki ${ }^{42}$. The residence of the Romanian legation was in Stockholm. This episode can be considered a setback in the evolution of the Romanian-Norwegian diplomatic relations. The appointment of a single representative for all Northern countries certainly limited the development of diplomatic relations at a high level because of the incomplete knowledge of the developments and specifics of these countries and their leaders.

The diplomatic activity performed by Paclianu continued in the footsteps of his predecessor, efforts being made to endorse the new Romanian realities. The fact that Greater Romania was discredited and contested in the Norwegian press as a result of real media campaigns ${ }^{43}$ nourished by new agencies belonging to Central European countries whose borders were altered as a consequence of the Trianon ${ }^{44}$ and Saint Germain peace treaties ${ }^{45}$ compelled the Romanian envoy to undertake an intense activity in the four Scandinavian countries in which he was accredited in order to deny these allegations. To illustrate this idea, I can mention the article entitled "The causes of war in the peace treaties. Europe's new irredentism. Hungary" (Fredstraktatenes krigsaarsaker. Europas Nye irredenta. II. Ungarn ${ }^{46}$ ) published in the newspaper Aftenposten on August 20, 1923. From a report submitted to Minister of Foreign Affairs of Romania Gheorghe Derussi one can learn that the Romanian diplomat was concerned about this news: "I gave precise instructions in various cases to our consuls to deny the bigoted and false news published regarding our country" 47 . Moreover, the interviews given by representatives of the

${ }^{41}$ Mihail M. Paclianu was a Romanian diplomat born in a boyar family from Buzau county. 42 Seim and Obiziuc, 51, Royal Decree no. 1306 of 16.03.1922.

43 AMAE 71 Norvegia vol. 13, Note no. 3141 of 01.03.1926 of M. Paclianu to the Romanian Minister of Foreign Affairs, IG Duca regarding the defamatory news from the Norwegian press.

44 The Trianon Treaty with Hungary (04.06.1920) refers to the Romanian-Hungarian border and recognition of the union of Transylvania, Banat and Maramures with Romania (Ioan Scurtu et al., ed., Istoria Romanilor, vol VIII, Romania Intregita (1918 - 1940) (Bucuresti: Editura Enciclopedica, 2003) 6.

45 The Saint Germain-en-Laye Treaty with Austria (10.12.1919) refers to the abolition of the Dual Monarchy of Austria-Hungary and the return of Bucovina to Romanian borders (Scurtu 2003, 6)

46 AMAE, Folder 71/1920-1944 Norvegia, Vol 4 - Press, 183-201, The article stated the idea according to which after the Peace Treaties that ended the First World War, millions of people suffer because of losing their territories that "were torn from their country and came under foreign occupation", but that no people is more affected than the Hungarian people.

47 Ibid., 289. Report no. 45082 dated August 27, 1924. 
The history of diplomatic relations between Romania and Norway during the interwar period

Romanian diplomacy to the Norwegian press emphasized the strengthening of the internal situation by Ion I.C. Bratianu government and by the monarchy who undertook a series of decisions in favour of the welfare of the people without making any differences of nationality ${ }^{48}$. The Romanian Legation also stressed the achievements of Romania's foreign policy placed in the hands of a great value man such as Nicolae Titulescu. This was part of the efforts undertaken by the Romanian legation in order to rehabilitate Romania's image in Scandinavian countries and uphold the solidity of the new political-administrative organisation of Greater Romania.

Meanwhile, the Norwegian government had expressed through its representative in Poland the desire to open a permanent office in Bucharest. ${ }^{49}$ Yet, as it had previously happened in case of Romania, this failed to materialize because of budgetary constraints. If during the WW I the Norwegian economic boom was indebted to its neutrality status which allowed it to develop trade relations with both warring sides, after 1920 its economy acknowledged a downturn which eventually worsened in the context of the Great Depression.

The Norwegian interests in Romania were represented by the Norwegian envoy in Rome, Johannes Irgens ${ }^{50}$, who was invited to attend the coronation of King Ferdinand I and Queen Maria at Alba Iulia and Bucharest in October 192251. Irgens's participation to this event of national significance to the Romanian people confirmed the links between the two royal houses as well as Romania's efforts to enlist the support of European states in the confirmation of its new borders. On this occasion, Irgens dispatched an extensive presentation of Romania and of the event to the Norwegian Foreign Minister Mowinckel and undertook a pertinent

48 Ibid., 220-222, Interview with the Romanian Charge d'Affaires in Oslo, Alexandru Guranescu in Oslo Aftenavis newspaper dated July 26, 1927.

49 Seim and Obiziuc, 48-49, Report of the envoy of Romania in Warsaw, Alexandru Florescu, to the Minister of Foreign Affairs of Romania no. 745 of 31.03.1920.

50 Johannes Irgens (1869-1939) was a lawyer, politician and Norwegian diplomat who maintained good relationship with the Romanian diplomats, being also a good connoisseur of the Romanian realities.

51 Ferdinand Victor Albert Meinrad of Hohenzollern-Sigmaringen (1865-1927), King of Romania in the period 1914-1927 was crowned on October 15, 1922 in Alba Iulia, King of Great Romania. Queen Marie of Romania, Princess of Saxe Coburg Gotha married Ferdinand of Hohenzollern on 29 December 1892 and conducted an intense activity in support of the Romanian cause in Western countries. The crowning event was attended by many Romanian politicians and foreign diplomats. Also, on this occasion on the steel crown of Carol I were symbolically added the symbols of the provinces united with Romania, Bessarabia, Bucovina and Transylvania. Scurtu 2003, 253. 
analysis of the international and domestic context 52 . The Norwegian diplomat proved a good knowledge of Romanian developments and concluded that the crowning event conveyed a strong message of national unity and strengthened the impression that the borders of Romania were correctly drawn. Irgens spent the last part of his trip in company of foreign diplomats attending the event, especially with the representatives of Sweden and Finland. He inferred from these discussions that the Romanian market represented an opportunity for Norwegian exports, so that the economic relations with this country needed to be strengthened. Thus, in early 1930, he prepared a note to the Romanian legation in the Italian capital to be presented to the Romanian government ${ }^{53}$. In the subsequent months negotiations started in Bucharest between Romania and Norway for a new commercial and maritime treaty ${ }^{54}$. The development of economic relations between the two countries was endorsed by the NationalPeasant ${ }^{55}$ government, a supporter of "open gates" economic doctrine.

The death of King Ferdinand I56 was mourned by the Royal Norwegian House over a period of three weeks. ${ }^{57}$ This was part of a complex of factors that marked a new stage in the history of diplomatic relations between Romania and Norway as a consequence of Romania's volatile domestic politics, global Great Depression and international instability. Internally, King Ferdinand I was succeeded at throne by his grandson Mihai ${ }^{58}$ under regency consisting of Prince Nicolae ${ }^{59}$, Patriarch Miron Cristea and lawyer Gheorghe Buzdugan. This situation spread

52 Seim and Obiziuc, 52-58, J. Irgens's report to the Norwegian Foreign Minister, J.L. Mowinckel no. 232 of 01.11.1922.

53 Ibid., Report of envoy of Norway to Rome J. Irgens to the Norwegian Ministry of Foreign Affairs on the Norwegian intention to negotiate a new commercial treaty with Romania; the note was handed to the Romanian Minister in Rome, Dimitrie I. Ghica. It shall be underlined that the old commercial and maritime treaty between the two countries was denounced by Romania in 1921.

54 Ibid., Irgens's report (who was named by the Norwegian Government responsible for treaty negotiations) regarding the meeting held in Bucharest on May 26, 1930 with the General Secretary of the Commercial Department of the Romanian Ministry of Foreign Affairs.

55 National Peasant Party, (http://www.ioanscurtu.ro/content/view/112/28/, accessed at 09.11.2011.

56 King Ferdinand I died on July 20, 1927 of intestinal cancer.

57 Seim and Obiziuc, 61.

58 Prince Mihai is the son of Carol II and nephew of King Ferdinand and Queen Mary. His father Carol II renounced to inherit Romania's throne on December 28, 1925 and Mihai became heir to the throne at the age of six and the successor of his grandfather. The monarchical powers were exercised by the regency, Scurtu 2003, 258.

59 Prince Nicolae was the second son of King Ferdinand and Queen Mary and brother of Prince Carol. 
The history of diplomatic relations between Romania and Norway during the interwar period anxiety within the Romanian political class ${ }^{60}$, which only grew worse with the deepening crisis caused by the intention of Prince Carol ${ }^{61}$ to return to his country and to lay claims to the throne. This state of affairs was reflected in the activity carried out by the Ministry of Foreign Affairs of Romania. Instability is also obvious with regard to the dynamics of appointments of diplomatic representatives abroad.

\section{8}

\section{Diplomatic relations between Romania and Norway after}

In this period Romania's interests in Scandinavia continued to be looked after by an envoy with residence in Stockholm who customarily travelled at least once a year to the other Scandinavian capitals. ${ }^{62}$ However, the large area the Romanians diplomats had to cover prevented them from attaining detailed knowledge of the specific realities of each country and from maintaining extensive contacts with the Scandinavian diplomacies. The immediate effect was that the Romanian-Norwegian relations acknowledged a setback and acquired a superficial character.

On February 1, 1928 Dimitrie C. Pennescu63, Romania's former envoy to Vatican, was appointed in the same quality to Stockholm, Oslo and Copenhagen ${ }^{64}$ with residence in the capital of Sweden. No fundamental changes can be observed in the priorities of the new envoy, one of his most important aims being to continue the work for the improvement of Romania's image in the Scandinavian countries.

60 In October 1926 when it was first learned that the health of King Ferdinand was worsening the political class showed an intense concern. In these circumstances Ion Mihalache, Vice-President of the National Peasant Party, supported the return of Prince Carol in the country as he considered that regency will possess "the powers of a monarch, but without moral responsibility of a monarch". The clashes between the supporters of the return of Prince Carol ("the carlists") and their opponents will continue until 1930 when the latter was enthroned as Carol II. Throughout this period governmental instability prevailed, Scurtu 2003.

61 Carol II of Hohenzollern-Sigmanringen (1893-1953) was Crown Prince (1914-1926) and King of Romania (1930-1940).In 1926 he informed his father that he had renounced forever to his right of inheriting the throne, Scurtu 2003.

62 AMAE 71 Norvegia Vol 4, 215, Report no. 593 of 15.08.1927.

63 Dimitrie C. Pennescu (1874-1938) graduated from the Law Faculty of Bucharest, was appointed since June 12, 1920 Romania's first diplomatic representative to the Holy See with the title of Envoy Extraordinary and Minister Plenipotentiary.

64 Seim and Obiziuc, Royal Decree no 5 of 02.01.1928 issued in Bucharest on behalf of King Mihai I by the Royal Regency established following the death of King Ferdinand I. 
After only two years, starting with March 1, 1930, Pennescu was replaced by the former envoy to Vienna Carol M. Mitilineu ${ }^{65}$ who was also required to watch over Romania's interests in Stockholm, Oslo and Copenhagen ${ }^{66}$. With the occasion of presenting his letters of accreditation to King Haakon VII of Norway, envoy Mitilineu undertook a visit to Oslo and gave an interview to newspaper Aftenposten. He expressed in this interview his intention to contribute to the intensification of the diplomatic, economic and cultural relations between the two countries ${ }^{67}$. The focus was however to be maintained on economic relations where more common interests existed that could form the bases of friendship relations between the two states. In this sense, the Romanian diplomat pointed out to the picturesque landscape, but also to the natural resources richness and to the agricultural potential of Romania, all of these providing favorable premises for Norwegian capital investment in Romania. Mitilineu wanted to convey a strong message of support to potential Norwegian investors and promised his personal assistance to them. Mitilineu's statements were also meant to encourage the negotiations for a commercial and maritime treaty between the two countries which were taken place in Bucharest. The person in charge with negotiating and signing of this treaty on behalf of Norway was Irgens, Norwegian envoy of Rome, who was in 1930 accredited to Bucharest, too. The negotiations overlapped with the political instability caused by the return in the country of Prince Carol who became the new sovereign of Romania ${ }^{68}$. Irgens reported these changes in his reports to the Ministry of Foreign Affairs of Norway. While Mitilineu was trying to reassure the Norwegian public opinion on the welfare of the Romanian people and the thrill Prince Carol's return in the country evoked to his compatriots, Irgens was concerned over the dynamics of Romania's domestic politics. In his report of June 7, 193069, the Norwegian diplomat

65 Carol M. Mitilineu (1865-1942) was a lawyer and diplomat who represented Romania in several European capitals, Vasilica Sarbu, Premiile Nobel pentru Pace in perioada interbelica (1918-1939) (Iasi: PhD thesis, Univ. Al. I. Cuza, 2010.)

66 Seim and Obiziuc, Royal Decree no. 284 of 30.01.1930.

${ }^{67}$ AMAE 71 Norvegia, Vol 4, 240-246, Minister Carol M. Mitilienu's report to the Romanian Foreign Affairs Minister, Prince Alexandru Vaida, on his visit to Oslo in order to present his credentials and the interviews he had given to the Norwegian press. The report is dated August 21, 1930.

68 Prince Carol took the advantage of the internal crisis caused by the divisions between the political parties and the discontent of the people with this situation and decided to return home to ascend to the throne of the country. Carol was restored as the King of Romania in June 8, 1930 under the name of Carol II, Scurtu 2003, 280.

69 Seim and Obiziuc, 71-74. Report regarding the return of Prince Carol in Romania, the domestic situation and the audience to Princess Elena of Romania and Queen Mary. 
reported about the social and political context70 of Prince Carol's return and considered necessary to hustle the signing of the commercial treaty because of concern of government change that might render futile all the efforts undertaken in the negotiations. The completing and signing of the treaty was equally important to both countries in the context of the global economic crisis. In Norway, the economic crisis caused by overproduction instantly reduced the shipping and export trade ${ }^{71}$, which determined the government to search for new markets outside the traditional partners ${ }^{72}$. Irgens' concerns proved to be unwarranted and the Commercial and Maritime Treaty between Romania and Norway was signed and fully came into force in $1931^{73}$.

Carol's assuming of the throne marked an increase of the Crown's role in Romania's external policy. Immediately after his coronation, the international press started to extensively discuss both the King's personal life and his propensity toward dictatorship. To limit such media news and interpretations spreading out, the Ministry of Foreign Affairs dispatched on September 12, 1930 a ciphered telegram to all diplomatic Romanian offices abroad whereby they were required to combat the negative news regarding the King and to cultivate a positive image of Romania ${ }^{74}$.

Princess Elena (1896-1982) was the wife of King Carol II and the mother of Prince Mihai, heir to the throne. The Princess married Prince Carol at the age of 24, but she was soon abandoned by her husband in favor of Elena Lupescu. Princess Elena divorced from Carol on July 21, 1928. When Carol returned to the country, his enthronement was accepted by the political class on the condition that he restored his marriage to Princess Elena, a promise he eventually shelved.

70 When Carol returned to the country the government was chaired by Maniu (President of the National Peasant Party). The PM had sworn to respect the laws of the country, including the law of January 4, 1926 which acknowledged the renouncing of Carol to the throne and instituted the Royal Regency. Carol's return to Romania placed Maniu in an awkward situation. He who could not disregard his commitments and therefore he proposed in the first phase to Prince Carol to join the Regency. But Carol's ambitions were far larger. Because the Liberal National Party would not support Carol's accession to the throne, he resorted to a series of maneuvers to sow strife in the Romanian political class. Maniu resigned from his position of head of government and was replaced by Gheorghe Mironescu (7-8.06.1930). Eventually, the Parliament decided the cancellation of the law of 4.01 .1926 and King Carol II was crowned before the Parliament and the foreign diplomats who attend to this event. The intervention of King Carol II in Romanian political life fostered political instability, Scurtu 2003, 284-285; Seim and Obiziuc, 74-76.

${ }^{71}$ Miloiu 2003, 160.

72 For example, Germany which mediated the commercial relations between Romania and Norway.

73 Seim and Obiziuc, Telegram of Romanian representative to Oslo, Alexander Flondor to the Romanian Minister of Foreign Affairs dated July 3,1931.

74 Scurtu 2003, 291. 
The second decade of the interwar period represented a crossroads in the evolution of international relations that affected the relations between the two distant European countries. The problems generated by the economic crisis were reflected both in the internal policy conduct of the European countries as well as in their foreign policy. Romania's foreign policy was gradually being affected by the dynamics of change in its international and domestic environments. Its geopolitical situation after the Great Union was already delicate. Although the structure of the country's borders was changed, the dangers at its gates were still present. Already from the dawn of the interwar period, Hungary, Soviet Russia and Bulgaria fostered a hostile attitude towards Romania, which tended to worsen in the second decade of the interwar period.

Meanwhile Norway was experiencing the negative effects of the economic crisis which generated strong political and social implications. Besides the economical problems caused by the loss of export and maritime trade of which Norway's economy strongly depended, the small Scandinavian nation also faced strong strikes of disgruntled segments of population. In this context, the internal political strife is not hard to imagine.

The economic crisis had also a negative impact on international relations by increasing the competition between great powers and threatening the world peace ${ }^{75}$. The alteration of international relations during the 1930s was caused by a complex of factors such as the ever more aggressive foreign policy of Nazi Germany, the tacit threats coming from the Soviet Union, Japan's expansion in China and Italy's intervention in Ethiopia, the revisionist policies of Hungary and Bulgaria and the lack of reaction from the League of Nations. All these events changed the course of international relations and dramatically lowered the prestige of the League of Nations. The small and middle sized states that previously regarded the existing international system of alliances as a security guarantee were forced to seek for protection outside the body of the League of Nations.

In these conditions that threatened to jeopardize its territorial integrity, Romania took a series of steps designed to strengthen its security ${ }^{76}$. These steps materialized in the concluding of a series of treaties and regional alliances ${ }^{77}$. While Romania was endeavoring to preserve its

\footnotetext{
75 Ibid., 463.

76 Romania continue "to woo" its traditional partners, France and Great Britain, and the Balkan neighbors. It also initiated the resumption of diplomatic relations with the Soviet Union, violently interrupted in January 1918.

77 Treaties were concluded with Poland, Czechoslovakia and the Yugoslavia. Romania, Czechoslovakia and Yugoslavia formed the Little Entente in 1921. On February 9, 1934
} 
territorial status-quo, Norway, with its pacifist tradition, sought to fortify its security without worrying too much about its territorial integrity. The reason was that Norway was surrounded by ocean on all frontiers except for the eastern side where it bordered Sweden and Finland, countries which were not regarded as a threat ${ }^{78}$. The geographical location at considerable distance from the major European powers and from the complications arising from their policies seemed to shelter Norway from any conflict. In its foreign policy, Norway carefully surveyed the foreign policy of three great powers: Britain, Germany and the Soviet Union. Of these, the relations with Britain were the most important both from an economic and political (strategic) point of view. British dominance of the North Sea guaranteed Norwegian security, so that Britain was regarded as a de facto sponsor of the security of the Scandinavian state. Germany, an important economic partner of Norway, was not perceived as a direct threat. The same can be said about the Soviet Union ${ }^{79}$, which however inspired a certain anxiety to the Scandinavian state. Norway believed that if "Moscow would try an attack by surprise, it will be surely directed against states which would oppose the weakest resistance, namely the small Baltic republics" 80 . So, Norwegian foreign policy rested on a certain sense of security that helped Oslo promoting during the interwar period a peaceful policy close to idealism. The Norwegian foreign policy idealism in respect of collective security proved to be erroneous. The lack of concern for a coherent security policy contributed to the fact that the country traversed in late 1930s one of the most dramatic chapters of its existence.

The events unfolding in Europe in the 1930s did not run without an echo in the Norwegian capital. Subsequently, the failure of collective security spawned real reasons of concern to the entire international community. In these circumstances, Norway showed an interest in Romania's foreign policy. ${ }^{81}$ Thus, in March 1931, the Romanian envoy to

Greece, Yugoslavia, Romania and Turkey signed the Balkan Entente in Athens. In May 1934 Romania resumed diplomatic ties with the Soviet Union.

78 After the collapse of the Union of Norway and Sweden in 1905, Sweden continued to be perceived as a threat by the Norwegian people, but this feeling diluted over time.

79 In the interwar period Norway signed with the Soviet Union important trade agreements advantageous to the economy, AMAE 71 Norvegia Vol. I, 6-7. Telegram no 892 of 3.07.1931.

80 Seim and Obiziuc, 78-79. Report no. 1642 of 21.08 .1930 of the Romanian Minister in Oslo,Carol Mitilineu regarding the audience at King Haakon and the sovereign's assessment of the international situation.

81 Seim and Obiziuc, 79-82. Discussion between Ove Vangensten, Norwegian Charge d'Affaires and Prince Ghika, the Romanian Minister in Rome on the strained relations between Romania and the Soviet Union. They also talked about Romania's relations with Italy, France and the Great Britain and possible help that Romania could receive in the event of a Russian attack. 
Rome Dimitrie I. Ghika ${ }^{82}$ notified the Romanian Government of the Norwegian Government's intention to appoint as minister plenipotentiary to Romania Sigurd Bentzon 83 , the envoy to Turkey. Henceforth, the diplomatic relations between Romania and Norway were to be conducted through the Norwegian Legation in Ankara. The Norwegian Government's argument was the geographical proximity of Ankara and Bucharest. Betzon was accredited in Bucharest from 1931 to 1934. A few months after his appointment, the diplomat undertook a visit to Romania wherein he brought into consideration the conclusion of an arbitration treaty between Romania and Norway. According to Norway's idealistic vision of international relations aimed at maintaining peace and security on the continent, most of the Norwegian politicians considered to be of vital importance the peaceful resolution of conflicts by means of arbitration. Norway, which lacked the WW I experience and where a sense of security prevailed in connection to the continental powers, had a different opinion than Romania in this respect. Unlike the Scandinavian state, Romania considered any means, whether diplomatic or military, to preserve its territorial integrity. Therefore, Romania was not interested in signing such an agreement. Hence, due to the aforementioned circumstances, the foreign policy means of the two countries were quite different in this respect, as evidenced on several occasions in the meetings of the representatives of the two countries.

Starting with June 1, 1932 for a brief period of time, Romania's interests in Norway were represented by envoy Matila Costiescu-Ghika ${ }^{84}$, who was named in the same capacity in Stockholm, Copenhagen and Helsinki (with residence in Stockholm) ${ }^{85}$. His mission in the Nordic countries ended a year later when the responsibility was transferred to Barbu Constantinescu ${ }^{86}$. The short time period of his nomination prevented the Romanian diplomat to carry out a perceptible activity.

Barbu Costantinescu, alike his predecessor, represented Romania's interests in Norway for about a year. Presenting his letters of accreditation

\footnotetext{
82 Seim and Obiziuc, 82. Report no. 586 of 20.03.1931.

83 Sigurd Bentzon (1877-1945) was a Norwegian diplomat who started his career in London in 1901 and represented the interests of his country in many other countries.

84 Matila Costiescu-Ghika (1988 - 1965) was a naval officer with an interest in philosophy (esthetician) and also a diplomat, writer, mathematician, engineer and historian. He began his diplomatic activity in 1910 in Romanian Legation in Rome. (http://ro.wikipedia.org/wiki/Matila_Ghyka).

85 Seim and Obiziuc, 93. Decree no 1762 of 20.05.1932.

86 Barbu Constantinescu represented Romania's interests in Norway from June 28, 1933 to April 15, 1934.
} 
to Oslo87, the Romanian diplomat obtained an audience with King Haakon in which the two interlocutors tackled economic, domestic and foreign policy issues regarding the two countries. Amid economic crisis, 1933 was to Norway a year of internal governmental instability that allowed the manifestation of the totalitarian current 88 , which was worrysome for an ultra democratic country like Norway. As regards the international developments, King Haakon of Norway voiced the antipathy of the Norwegian public opinion against Germany in general and against Hitler particularly, which culminated in the lowering of the prestige of this country in Norway. The Norwegian sovereign also expressed his admiration to Great Britain's political and constitutional traditions and saw in this state a model. The conversation served to evaluate the position of the two countries regarding the international situation. During his accreditation to Oslo, Barbu Constantinescu reported on Romania's image in the Norwegian press ${ }^{89}$. According to widely circulated newspapers listed by the diplomat ${ }^{90}$, there was a favorable current towards Romania. Consequently, the Romanian efforts vis-à-vis the Norwegian press had managed to achieve their goal, i.e. to combat unfounded rumors about Romania and replace them with a favorable image of the country.

Both the government in Oslo and the one in Bucharest felt that the appointment of zonal representatives did not adequately serve the interests of the two countries. In order to strengthen the diplomatic relations between Romania and Norway, the Romanian Government requested through Barbu Constantinescu the approval of its Norwegian counterpart for the appointment of Dimitrie Jurascu ${ }^{91}$ as envoy of Romania to Oslo ${ }^{92}$. Jurascu received his appointment by royal decree on April 15, $1934^{93}$ and obtained

\footnotetext{
87 AMAE, 71 Norvegia 1933-1939, vol. 13, 97-100.

88 Vidkun Quisling (1877 - 1945) was born into a family of Danish immigrants, completed Military Naval Academy in 1908 and showed sympathy to totalitarian regimes. From 1931 to 1933 he was Minister of Defense. Since 1933 he promoted in the Norwegian press the ideal of establishing a dictatorship to solve the economical and social implications of the global crisis. To this purpose Quisling launched on May 16, 1933 his own pro-fascist party called Nasjonal Samling (National Unity Party). In this framework, in Norway appeared more and more supporters of Germany and Hitler, but the low electoral performances of Quisling's party and the strong democratic tradition of Norwegian people prevented this from gaining a momentum. As a result of his fascist actions, at the end of WWII Quisling was declared traitor and shot dead, Miloiu 2003, 160.

${ }^{89}$ AMAE 71 Norvegia, vol 4, Media, non-paged. Report no. 1835 of 07.12.1933.

90 Nationen, Norges Handels, Morgenbladet, Aftenposten, Morgenposten, Tidens Tegn.

${ }^{91}$ Dimitrie Jurascu (1894-1962) was a Romanian diplomat and jurist born into a boyar family in Moldova, Vasilica 2010.

92 Seim and Obiziuc, 97. Telegram no. 17676 of 29.03.1934.

93 Ibid., 97. Decree no. 1010 of 5.04 .1934$.
} 
the agreement of the Norwegian Ministry of Foreign Affairs on April 2694, this date marking the reopening of the Romanian embassy in Norwegian capital. The setting up of a permanent diplomatic mission in Norway led to a better collaboration between the two countries in both foreign policy and economic exchanges.

The merit of this demarche must be attributed to the Romanian Foreign Minister Titulescu who was always concerned with establishing diplomatic relations with as many countries as possible in order to increase Romania's influence on the international scene. The establishment of permanent diplomatic offices in the capitals of Scandinavian countries ${ }^{95}$ was also due to the perception that these countries "enjoy a certain moral authority in international relations" 96 . Besides foreign policy reasons, there were also economic motives behind this decision.

Romania's economic interests and goals regarding Norway are highlighted by Jurascu in an interview he gave to the respected economic newspaper Norges Handels og Sjofartstidente ${ }^{97}$. Between the two countries important commercial exchanges according to the provisions of the commercial and maritime treaties of 1910 and 1931 were taking place. Norway was an important supplier of fish products to Romania, while the latter country was sending large quantities of grains through Norwegian ports. Nevertheless, there was a decrease in the export of Romanian products to Norway and the Romanian diplomatic office aimed to change this situation ${ }^{98}$.

The improvement of the diplomatic and economic relations between the two countries and the ius non scriptum of reciprocity required the opening of a permanent Norwegian diplomatic office in Bucharest. Jurascu advocated with the political circles in Oslo in favor of correcting the diplomatic anomaly between the two countries ${ }^{99}$. After a meeting with the Norwegian Minister of Foreign Affairs Koht, Jurascu obtained the appointment of a Chargé d'affaires in Romania starting with October

\footnotetext{
94 Ibid., 98-99.

95 In Stockholm, Copenhagen and Oslo.

96 Oana, Popescu Romania si Danemarca in prima jumatate a secolului XX, (Targoviste: Editura Cetatea de Scaun, 2010), 55.

97 AMAE 71 Norvegia, vol 13. Non-paged. Note no. 595 of 31.07.1935.

98 Following the end of the First World War in order achieve homogenization of the new political-administrative realities of Greater Romania a series of social and economic reforms were adopted. In the second decade of the interwar period, they caused an increase in agricultural production and improved the situation of the Romanian economy even more as the effects of the Great Depression began to diminish. In this context, Romania sought to identify new markets for its agricultural products, including Northern European countries. 99 Seim and Obiziuc, 103-104. Report no. 248 of 27.03.1935.
} 
1935100. An exchange of diplomatic notes between the foreign ministers of the countries, Titulescu and Koht, provided for the accreditation of the Norwegian diplomat Terje Knudson ${ }^{101}$ as chargé d'affaires in Bucharest with permanent residence in the capital of Romania ${ }^{102}$ and for the recall of Bentzon ${ }^{103}$. The significance of the opening of a Norwegian Legation in Bucharest was highly evaluated by Knudson who after three months spent in Romania remarked that he could not imagine how the diplomatic relations between the two countries evolved in absence of permanent legations ${ }^{104}$. The progress in the representation of the interest of the two countries may be viewed as a result of both the maturation of their relations and of some common interests in the international developments. In contrast to the previous period when the diplomatic relations between Romania and Norway were mediated through third countries' capital cities, the opening of permanent diplomatic missions in Bucharest and in Oslo contributed not only to the development of the diplomatic relations between the two countries and but also lent them a linear and well organized character. Subsequently, the two heads of legation will maintain their functions until the beginning of WW II.

\section{Diplomatic relations between Romania and Norway at the eve of World War II}

The diplomatic relations between Romania and Norway became more intense on the eve of WW II as demonstrated by the increased frequency of diplomatic dispatches. The intensification of diplomatic relations between the two countries can be explained in two ways. If the existence of permanent diplomatic offices in the two capitals provided the ties between the two countries with the institutional framework to facilitate their growth, the international developments should not be overlooked. The strained international climate required a better collaboration between the small and medium states who perceived themselves as being threatened as a result of the clashes between Europe's Great Powers.

\footnotetext{
100 AMAE 71 Norvegia, vol 13. Non-paged.

101 Terje Knudson (1886-1953) was a Norwegian diplomat with extensive diplomatic experience. He was the representative of his country in states such as Brazil, Japan, Cuba and Poland.

102 Seim and Obiziuc, 105.

103 Between the departure of Bentzon and the arrival of Knudson in Bucharest there was a break of several months during which the relations between the two countries were carried out through the Norwegian embassy in Poland, the Norwegian Minister in Warsaw, Christian Nielns Ditleff, being accredited to Bucharest, Seim and Obiziuc, 106, note 38. 104 Ibid., 113. Terje Knudson's report no. 40 of 10.02.1936 regarding his activity in Romania from November 1935 to February 1936.
} 
Without perceiving any direct threat from the big powers, Norway closely monitored the international developments. The conversations of Romanian envoy Jurascu with the Norwegian Foreign Minister Mowinckel also approached the growing tension among the European states ${ }^{105}$. Also, with the stated purpose of promoting peaceful international relations, the Norwegian chief of diplomacy welcomed the improvement of the Romanian-Soviet relations ${ }^{106}$. Additionally, Oslo's positive attitude towards the Romanian-Soviet rapprochement can be explained in the context of Norway's friendlier stance towards Soviet Union than towards Nazi Germany. The imperialist policy as pursued by Germany engendered a feeling of fear within the Norwegian public opinion. In respect to Soviet Union, the Norwegian Government started to move towards a more positive attitude, which is proven by the improvement of the economic relations between the two countries. ${ }^{107}$ Gradually, the Romanian-Soviet relations started to cool down after the replacement of Titulescu from the position of Foreign Minister. Subsequently, Norway's attitude in respect to the Romanian foreign policy will be affected by the different perspective of the two countries regarding the two great powers. Threatened by the revisionism of its neighbors (the Soviet Union included), Romania sought a rapprochement with Germany rather than with the USSR.

Jurascu carried out an intense diplomatic activity in Oslo and maintained good relations with the Norwegian political elite and especially with Foreign Minister Koht ${ }^{108}$ whom he met frequently. In their meetings

105 AMAE 71 Norvegia, vol 13, 101-103. Chipered telegram recorded as no. 29.124 of 29.05.1934 from D. Jurascu to the Romanian Foreign Minister N. Titulescu. During the discussions, JL Mowinckel referrred especially to the growing tension between France and Germany amid developments leading to the Franco-Soviet collaboration. Germany perceived this cooperation as a threat to its eastern borders. In the context of the deterioration of the German-Soviet relations, the Soviet Union acknowledged a fundamental change in its policy and started to show support to the maintaining of peace through alliances signed with continental European countries. This resulted into its acceptance in the League of Nations on September 18, 1934 to the dismay of some Member States such as the Norway which at the time had not trust in the Soviet policy, AMAE 71 Norvegia, Vol. 1, 71 73.

106 The Romanian-Soviet negotiations in Riga of January 1932 on the signing of a nonaggression pact ended unsuccessfully, but at the Conference on Disarmament in Geneva negotiations were resumed and completed in May 1934 with the restoration of diplomatic relations between Romania and the USSR (exchange of diplomatic notes 09.06.1934).

107 AMAE 71 Norvegia, Vol 13, Relations with the USSR, 236-237, Report no. 667 of 18.05 .1931 on improving trade relations between Norway and Russia to support the two governments in this sense.

108 Halvdan Koht reorganized Norway's foreign policy direction under the impact of the apparent failure of the League of Nations. Thus, in 1936 Norway joined Sweden, Denmark, 
the two diplomats discussed issues regarding their countries' economic ties, their domestic policies and the evolution of the international relations. The purpose of these meetings was customarily to analyze the attitude of the two countries towards the great powers and the tense European atmosphere which heralded a new world conflagration. In his dispatches to Titulescu, Jurascu also revealed the attitude of the Norwegian political elite towards the League of Nations: "many believe that there can be no world body, not even of European nature, capable of a peaceful reorganization of the peace of our continent, but in the future we should assemble «an alliance of Western European states as the only way to remove the fears regarding a new war which threatens us»"109. The foreign policy direction taken by Oslo regarding the international situation was that "Norway will keep itself at all costs away from being drawn into a war. Norway wants to bring an effective peace policy into the League of Nations" 110 .

Romania's position towards the League of Nations remained the traditional one, the aim being the maintenance of the country's territorial integrity. Knudtzon confirmed in his diplomatic dispatches this foreign policy orientation of Bucharest ${ }^{111}$. He also approached the newly established Royal Dictatorship in Romania and the characteristics of this form of leadership. His rich diplomatic experience allowed him to observe the subtlest nuances and the most intimate features of Romanian domestic politics. His analyses would not overlook the economic and social developments. For instance, Kundtzon's reports frequently approached the treatment of the Jewish minorities in the circumstances of the Romanian foreign policy's reorientation towards Germany.

In 1938 Paul Koht112, the son of the Norwegian Foreign Minister replaced Kundtzon as chargé d'affaires in Bucharest. The new chargé d'affaires continued to focus his activity on a careful analysis of the evolutions in Romania. However, he will be soon replaced by another in chargé d'affaires, Ferdinand Carl Sandberg113, who held this position from 1939 to 1941. Sandberg's dispatches emphasized Romania's growing concerns with regard to the aggressive foreign policy of Germany114. The

Finland, Netherlands, Spain and Switzerland in their decision not to support unwarrantedly the sanctions system of the League of Nations, Miloiu 2003, 162.

109 Seim and Obiziuc, 126-127.

110 AMAE 71 Norvegia, Vol 3, 6-10. Report no. 122 of 03.02.1938.

111 Seim and Obiziuc, 140-141. Report no. 52 of 21.02.1938.

112 Paul Grudem Koht (1913-2002) was son of politician Halvdan Koht and started his diplomatic career in 1938 as Charge d'Affaires in Bucharest.

113 Carl Ferdinand Sandberg (1880-1954) was a Norwegian jurist and diplomat, representing the interests of his country in several states.

114 Seim and Obiziuc, 168. Report no. 38 from March 1939. 
The history of diplomatic relations between Romania and Norway during the interwar period

Reich's occupation of Czechoslovakia115 triggered panic among the Romanian public and the government felt the need to censor the press regarding this topic.

Concerns spread to Oslo, too. The Romanian chargé d'affaires in the Norwegian capital Alexandru Georgescu submitted a diplomatic report in March 1939116 that reads as it follows:

"I found Mr. Koht very pessimistic in regard of the international political situation (...) The fact that England is moving so slowly, having not introduced the compulsory military service so far engendered an immense feeling of insecurity among the small states. Norway's situation is not identical to that of Czechoslovakia, yet with the new mentality manifested recently by the leaders of some of the great powers, it is not to be excluded that this country may also be subject of an attack".

Foreign Minister Koht's statement can be explained in the circumstances in which Norway stood at the crossroads of the relations with the powers on which it depended economically as well as politically and strategically, i.e. Germany and Great Britain. Unlike the situation during World War I when Norwegian neutrality was protected by the British domination of the North Sea, technological development, especially in aviation, deeply affected the international setting for Norway. ${ }^{117}$ The small Scandinavian state started to be not as inaccessible in geographical terms as it was the case before. Since 1937 and especially from 1939 Norway sought to strengthen its military power ${ }^{118}$. Although adopting a policy of neutrality ${ }^{119}$, Norway would not forfeit its trade relations with the League of Nations' countries or with those staying outside this

115 On September 30, 1938, in Munich, France, Britain, Italy and Germany decided to sacrifice Czechoslovakia's territorial integrity, this country being forced to surrender territory to Germany, Poland and Hungary. The panic created among the Romanian people is explained by the fact that Czechoslovakia was seen as falling prey to its neighbors' revisionist threats, threats that were not unfamiliar to Romania, too.

116 AMAE 71 Norvegia, Vol 3, 137-138. Report no. 393 of 25.03.1939.

117 Olav Riste, Norway's Foreign Relations. A History (Oslo: Universitetsforlaget, 2001).

118 Prime Minister of Norway Juhan Nygaardsvold (1859-1972) supported the preparation of Norwegian military forces to cope with a possible attack. Nygaardsvold, who served as PM from 1935 to 1945 , also undertook a series of social and economic measures designed to strengthen the welfare of his nation, Miloiu 2003, 162.

119 AMAE 71 Norvegia, Vol 4, 95-96. Report no. 1072 of 29.08.1939 from Romanian Charge d'Affaires in Oslo, Emil Zarifopol, to the Romanian Minister of Foreign Affairs, regarding Norway's towards the outbreak of a possible war. After a talk with Carl Joachim Hambro, the President of the Storting, Zarifopol concluded that Norway will take all necessary measures to preserve its neutrality. 
organization. Norway would not adopt any sanctions against Germany after March 1936 because of concern that they would have a strong negative impact on the Norwegian economy.

On the other hand, Romania felt the need to increase its efforts designed to conserve its territorial integrity ${ }^{120}$, the more so as the internal situation grew tenser ${ }^{121}$.

On the eve of the WW II, on both sides, the diplomatic dispatches show the anxiety of the two countries regarding the evolution of the international situation and the prospect of an impending war. Yet, the imminence of the outbreak of a new war set the diplomatic relations between Romania and Norway on a downward course.

Despite Norway's economic policy favorable to Germany, the latter power would not hesitate to attack and occupy the Nordic state in spring 1940. Emil Zarifopol, chargé d'affaires in Norway's capital, reported on the precipitating evolutions in Oslo ${ }^{122}$. Regarding the situation of Romanian Legation, Zarifopol confessed in an undated and confidential report:

"Since the day of the occupation, the 9th of April, foreign legations and consulates have ceased to have any contact with the outside world. Letters don't arrive from outside and the ones dispatched are of course subject to censorship. They are allowed to correspond with their governments by telegraph, preferably in clear, and the correspondence with their colleagues in neighboring legations such as the ones in Stockholm, Berlin, etc. is brought to a standstill. The use of diplomatic couriers is not authorized but with a few exceptions granted only to the Swedish, Finnish, American, etc. legations"123.

120 In this period Romania remained faithful to close ties with Britain and France and took a series of measures both internally and externally to prevent a possible attack.

121 Carol II's royal dictatorship ran from 1938 to 1940. Romania acknowledged in this period a shift from a democratic regime to a system of authoritarian monarchy. On 10/11 February 1938 the King established a state of siege on Romania's territory, startd to censor the press, etc., and a few days later a new Constitution was adopted which outlawed all political parties but National Rennaisance Front and gave the King the right to govern the country. Romania's internal political strifes are faithfully reported in the documents prepared by the Norwegian Charge d'Affaires in Bucharest, C.F. Sandberg.

122 Seim and Obiziuc, 186-187. Report no. 355 of 07.03.1940. After a month during which they hid inside the country, The Norwegian Government and the King escaped to Great Britain from where they will lead an intense campaign designed to free their country. The Norwegian delegation was accompanied by the envoys of Great Britain, France and Denmark, while Sweden, Finland and Romania's envoys were left behind to the dismay of Zarifopol. See also General Titus Garbea, Memorial si insemnari zilnice, vol. 1, ed. Silviu Miloiu (Targoviste: Editura Cetatea de Scaun, 2011).

123 Seim and Obiziuc,190-194. 
Norway capitulated on June 7, 1940 and starting with July all foreign legations in Oslo were closed down.124 As for the Norwegian legation in Bucharest, it continued to operate until February 1941. In a message dated February 11, 1940, the Foreign Minister of the Norwegian Government based in London requested that the chargé d'affaires in Bucharest should leave Romania as soon as possible and head to Belgrade, where he was accredited ${ }^{125}$. The documents mention that this should not be interpreted as a breach of diplomatic relations. However, the diplomatic relations between Romania and Norway will remain frozen during the WW II.

\section{Conclusions}

The history of diplomatic ties between Romania and Norway in the interwar period was generally characterized by the efforts of the two countries to intensify their relations. These efforts resulted in the setting up of legations in Christiania/Oslo in 1917 and again in 1934 and in Bucharest in 1935. An overview of the history of their diplomatic bonds during this period should consider as time limits May 16, 1917, the date of foundation of the first Romanian legation at Christiania, and July 15, 1940 and February 1941 respectively, when the ties were broken off as a result of the violent occupation of Norway by Nazi Germany. For most part of the interwar period, the diplomatic relations between Romania and Norway were maintained through legations located in other European capitals. The absence for a long period of permanent diplomatic offices in Bucharest and Oslo shall not be interpreted as an expression of lack of mutual interest, but shall be rather attributed to the budgetary constraints limiting the two countries' ability to conduct a more active foreign policy in relation with states situated beyond their immediate neighborhood and the circle of great powers. Moreover, the frequent changes of the envoys accredited in the two capitals affected the possibility of pursuing high level and stable diplomatic relations. Nevertheless, the Romanian envoys' activity in the Norwegian capital advanced Romanian interests in this country. The Romanian propaganda in the Norwegian press was not irrelevant as regards Romania's prestige on the international arena if we take into consideration that the media mediated the perceptions of each other of the two peoples. This was even more important if we also consider the considerable geographical distance separating the two countries.

\footnotetext{
124 Terje Leiren, "A Century of Norwegian Independence“, Scandinavian Review 92, no. 3 (Spring 2005): 6.

125 Seim and Obiziuc, 196-197.
} 
Behind the development of the relations between the two distant countries such as Romania and Norway stood to a large extent their economic and commercial interests, both countries trying to find markets for their products. Although the economic interests constituted the engine of the evolution of their diplomatic relations, the progress of their diplomatic bonds was also indebted to Romania's interests of getting acknowledgement and support for the Great Union of 1918 and to Norway's desire to set up its own network of international relations following its separation from Sweden in 1905.

In the context of the interwar international relations, the diplomatic relations between Romania and Norway remained secondary to the ties fostered with their neighboring states and with the European great powers towards which the two countries exhibited a special interest. Therefore, the diplomatic relations between Romania and Norway in the interwar period can be considered peripheral, but by no means can they be regarded as irrelevant both in the context of their foreign policy and in relation to the system of international relations.

\section{References:}

\section{A. Archives:}

Arhivele Diplomatice ale Ministerului Afacerilor Externe al Romaniei [The Diplomatic Archives of the Romanian Foreign Ministry, AMAE], Folder 71/1920-1944, Norvegia: volumes 1, 3, 4, 11 and 14 .

\section{B. Published documents and diaries:}

Garbea, Titus. Memorial si insemnari zilnice, vol. 1. Ed. Silviu Miloiu. Targoviste: Editura Cetatea de Scaun, 2011.

Preda, Dumitru, Ed. Romania la Conferinta de Pace de la Paris (19191920). Bucuresti: Editura Semne, 2010.

Seim, Jardar and Stelian Obiziuc et al, Eds. Romanian-Norwegian Relations, Diplomatic Documents, 1905-1947. Bucuresti: Institutul Cultural Român, 2007.

\section{Books and articles:}

Ciuperca, Ion. Romania in fata recunoasterii unitatii nationale. Repere. Iasi: Editura Universitatii „Al. I. Cuza”, 1996. 
The history of diplomatic relations between Romania and Norway during the interwar period

Miloiu, Silviu. „Fețele schimbătoare ale stângii norvegiene de la jumătatea anilor 1930: percepții şi reacții româneşti." In Politică, diplomație şi război. Profesorul Gheorghe Buzatu la 70 de ani. Coord. Sorin Liviu Damean, Marusia Cârstea. Craiova: Ed. Universitaria, 2009.

Miloiu, Silviu, Oana Laculiceanu-Popescu, Elena Dragomir. O conceptie romaneasca a Nordului, sec. XIX-XX. Targoviste: Editura Cetatea de Scaun, 2009.

Miloiu, Silviu. O istorie a Europei Nordice si Baltice. De la epoca nationalismului la Razboiul Rece, Vol. I. Targoviste: Editura Cetatea de Scaun, 2003.

Platon, Gheorghe et. al., Ed. Istoria Romanilor. De la indepenendenta la Marea Unire (1878 - 1918), Vol. VII, Tom. II. Bucuresti: Editura Enciclopedica, 2003.

Popescu, Oana. Romania si Danemarca in prima jumatate a secolului XX. Targoviste, Editura Cetatea de Scaun, 2010.

Riste, Olav. Norway's Foreign Relations. A History. Oslo: Universitetsforlaget, 2001.

Sirbu, Vasilica. Premiile Nobel pentru Pace in perioada interbelica (19181939). Iasi: Ph.D. Thesis, Univ. Al. I. Cuza, 2010.

Scurtu, Ioan, Coord. Istoria Romanilor. Romania Intregita (1918 - 1940), vol VIII. Bucuresti: Editura Enciclopedica, 2003.

Terje, Leiren. A Century of Norwegian Independence." Scandinavian Review 92, no. 3 (Spring 2005).

\section{Web postings:}

Scurtu, Ioan - Istoria romanilor intre anii 1918-940, Pactul Societatii Natiunilor. http://ebooks.unibuc.ro/istorie, accessed at 20.04.2011.

http://www.ioanscurtu.ro/content/view/112/28/, accessed at 09.11.2011. 